GRAÇA AJP; AMARAL JÚNIOR AT; RODRIGUES R; GONÇALVES LSA; SUDRÉ CP; VIVAS M; MELO PCT. 2015. Heterosis and combining ability of dual-purpose tomato hybrids developed to meet family farmers' needs in Brazil and Mozambique. Horticultura Brasileira 33:339-344. DOI: http:// dx.doi.org/10.1590/S0102-053620150000200010

\title{
Heterosis and combining ability of dual-purpose tomato hybrids developed to meet family farmers' needs in Brazil and Mozambique
}

\author{
António JP Graça'; Antonio T Amaral Júnior²; Rosana Rodrigues²; Leandro SA Gonçalves³; Cláudia P \\ Sudré́; Marcelo Vivas²; Paulo CT Melo ${ }^{4}$ \\ ${ }^{1}$ Ministério da Agricultura, Direção Nacional de Serviços Agrários, Maputo, Moçambique; jacintograca@yahoo.com.br; ${ }^{2}$ Universidade \\ Estadual do Norte Fluminense Darcy Ribeiro, UENF-LMGV, Campos dos Goytacazes-RJ, Brasil; amaraljr@uenf.br; rosana@uenf.br; \\ cpombo@uenf.br; mrclvivas@hotmail.com; ${ }^{3}$ Universidade Estadual de Londrina,UEL-CCA, Londrina-PR, Brasil; lsagrural@yahoo. \\ com.br; ${ }^{4}$ Universidade de São Paulo, USP-ESALQ, Depto. Prod. Vegetal, Piracicaba-SP, Brasil; paulomelo@usp.br
}

\begin{abstract}
Brazil is the world eighth largest tomato producer and, within the country, the tomato production chain is segmented according to fruit destination: fresh consumption and processing (industrial supply). In contrast, Mozambique does not have a differentiated chain and cultivars are expected to serve both purposes. As there are no tomato breeding programs in Mozambique, cultivars used in the country come from other regions of the world, including Brazil. This paper describes the development and assessment of tomato hybrids with dual-purpose: fresh use and processing. Five tomato genotypes (B13LD, Castone, Massag-72, "Viradoro", and "Rio Grande") were crossed in complete diallel design without reciprocal, and the general and specific combining ability (GCA and SCA) and heterosis were estimated to ten agronomic and fruit quality traits. The offspring of cross B13LD x "Rio Grande" showed potential for use in dual purpose, considering SCA and heterosis estimates for fruit firmness (FF), total content of soluble solids (TSS), number of fruits per plant (NFP) and yield (YLD). Combinations B13LD x Castone, Massag-72 x "Viradoro", and Massag-72 x "Rio Grande", although having no strength to increase YLD, had positive heterosis for FF, TSS, and NFP. The development of high-yielding genotypes, with agronomic traits that meet the expectations of both markets are a breakthrough for Mozambican tomato producers and may also be very convenient to family farmers in Brazil. In both countries, these dual-purpose cultivars represent the freedom of choice to farmers, who will be then in position to allocate their production to the most profitable market segment.
\end{abstract}

Keywords: Solanum lycopersicum, breeding, fruit quality, agroindustry, processing, international cooperation.

\section{RESUMO}

Heterose e capacidade combinatória de híbridos de tomate de dupla finalidade para atender produtores familiares no Brasil e em Moçambique

O Brasil é o oitavo produtor mundial de tomate e, no país, a cadeia produtiva do tomate é segmentada de acordo com a finalidade de uso do fruto: consumo in natura ou processamento. Ao contrário do Brasil, Moçambique não possui cadeia diferenciada e as cultivares são utilizadas para atender a ambos os mercados. Como não existem programas de melhoramento de tomateiro em Moçambique, as cultivares utilizadas são oriundas de outras regiões do mundo, inclusive do Brasil. Este trabalho descreve a obtenção e avaliação de híbridos de tomateiro com uso potencial em dupla finalidade: mercado fresco e agroindústria. Cinco genótipos de tomateiro (B13LD, Castone, Massag-72, "Viradoro" e "Rio Grande") foram cruzados em esquema de dialelo completo, sem recíprocos, e as capacidades geral e específica de combinação (CGC e CEC) e a heterose foram estimadas para dez caracteres agronômicos e de qualidade de frutos. Entre os híbridos avaliados, a combinação B13LD x "Rio Grande" mostrou potencial para uso em dupla finalidade, considerando-se as estimativas de CEC e de heterose para firmeza de frutos (FE), teor total de sólidos solúveis (TSS), número de frutos por planta (NTFP) e produtividade (PROD). As combinações B13LD x Castone, Massag-72 x "Viradoro" e Massag-72 x "Rio Grande", embora não tenham potencial para proporcionar aumentos em PROD, tiveram heterose positiva para características FE, TSS e NTFP. O desenvolvimento de genótipos com alta capacidade produtiva e características agronômicas que atendam aos dois tipos de mercado são um avanço para os produtores de Moçambique e podem igualmente ser úteis a produtores familiares no Brasil. Em ambas as situações, os produtores passarão a dispor de cultivares desenvolvidas para dupla finalidade e assim poderão destinar sua produção para o segmento de mercado mais lucrativo.

Palavras-chave: Solanum lycopersicum, melhoramento genético, qualidade de frutos, agroindústria, processamento, cooperação internacional.

(Recebido para publicação em 20 de janeiro de 2014; aceito em 27 de fevereiro de 2015) (Received on January 20, 2014; accepted on February 27, 2015)

$\mathrm{T}_{2}$ omatoes (Solanum lycopersicum) are grown in many different latitudes around the world. In 2011, tomato production in the world reached
159.02 million tons, with the three top producers, namely China, India, and 
the United States, accounting for about $50 \%$ of the total (FAO, 2013). Brazil, the eighth world producer, harvested in 2011, 4.42 million tons, in 69.310 ha, with an estimated yield of $63.85 \mathrm{t} / \mathrm{ha}$ (IBGE, 2012; FAO, 2013).

In the last 20 years, Brazil has been experiencing promising results with tomato breeding programs. The country has jumped from an average yield of $37 \mathrm{t} / \mathrm{ha}$ in 1990 to $63.85 \mathrm{t} / \mathrm{ha}$ in 2011 (IBGE, 2012). Among the vegetable crops, tomato had the highest number of cultivars registered in the Brazilian Ministry of Agriculture, Livestock and Food Supply (MAPA). There were 1,044 tomato cultivar records between $1998-2010,95.69 \%$ of them out of the private sector (Marinho et al., 2011). In Brazil, tomato breeding programs are carried out both by public and private institutions, with most of the hybrids being produced by multinationals (Marinho et al., 2011; Ramalho \& Araújo, 2011). As result of technological progress and cultivar development, tomatoes are directed either to industrial supply or to fresh consumption, these two distinct production segments using cultivars with different growth habits (Camargo et al., 2006). Nevertheless, whenever there is shortage in the fresh market supply, industrial tomatoes are promptly diverted also to this end.

In contrast with the Brazilian picture, in 2011 Mozambique harvested 195.000 tons of tomatoes, in 14.000 ha, which resulted in an average yield of $14 \mathrm{t}$ / ha (MINAG, 2011), among the lowest in the world. Still, tomato is one of the most widely grown vegetables in Mozambique, second only to potatoes. Tomatoes are relevant as food for Mozambicans, but its importance goes much beyond, positively impacting employment and incomes, rural development and agribusiness. Most of the production comes from highly heterogeneous smallholders, who use mainly river shores, ponds and irrigated areas, smaller than 1 ha, for agriculture. Mozambique has a diversity of agroecological zones, which allows tomato to be planted throughout the year. The main producing zones are the valleys of rivers Incomati and Umbelúzi, in Maputo; Limpopo, in Gaza; the plateau regions of Manica and Angónia, in Tete; Lichinga, in Niassa, and; Licuari and Lioma, in Zambezia. Despite the favorable conditions, production is seasonal and uneven, concentrated in the cool season, from March to September.

The main cultivars in the Mozambican market are commonly purchased in South Africa, USA, and in the European Union. Some tomato cultivars on the market are Cal J, UC82b, Rome, Marglobe, Rio Grande, Rio Fuego, HTX, Sunday, Angela, Chicago, Star Zourmored, and Kilele. In Mozambique, there is no fruit use segmentation in the tomato chain, and any type of tomato has, in practice, dual purpose, fresh consumption and industry. Although most of these cultivars are lagged to local agroecological conditions, they go on being used due to several reasons, including the lack of technicians and researchers to plan, lead and implement local breeding programs in vegetable crops (Melo, 2011).

Given this, this paper describes the development and evaluation of tomato hybrids potentially suitable for both the fresh market and the processing industry, aiming at offering options to scale-up the tomato production chain in Mozambique, but also alternatives to the Brazilian market.

\section{MATERIAL AND METHODS}

Five tomato genotypes with fruits of dual use, fresh market and processing, were intercrossed in a complete diallel design without reciprocal crosses, obtaining a total of ten hybrids. Out of the five parent genotypes, three are lines (B13LD, Castone, Massag-72) kindly assigned by professor Paulo César Tavares de Melo, from Universidade de São Paulo - Escola Superior de Agricultura Luiz de Queiroz (USPESALQ), while the other two are cultivars Viradoro and Rio Grande (ISLA seeds). Line B13LD is resistant to Verticillium spp., Fusarium spp. and Pseudomonas syringae pv. tomato. Fruits are firm, elongated and oblong, without the stem abscission layer, bright red and with a high content of soluble solids ( ${ }^{\circ}$ Brix). Line Castone is also resistant to Verticillium spp., Fusarium spp., and Pseudomonas syringae pv. tomato, with an additional resistance to Stemphylium spp. Fruits ripe early, are medium in firmness, highly uniform and bright red. Line Massag-72 is resistant to Verticillium spp. and Fusarium spp. and has firm elongated pear-shape fruits.

The hybridization step was performed in a greenhouse, at the Unidade de Apoio à Pesquisa of Universidade Estadual do Norte Fluminense Darcy Ribeiro (UENF), in Campos dos Goytacazes, Rio de Janeiro. For each parent, eight plants were used. Plants grew in pots containing a 2:1 mixture of soil and the commercial substrate Vivatto $^{\circledR}$, fertilized with $30 \mathrm{~g}$ of 4:14:8 NPK. Pollen was collected in recently opened flower buds and stored in starch capsules, in containers with silica gel properly identified, under refrigeration. Crosses were carried out in the morning, from 6:00 to $10: 00$, in flowers previously emasculated. Emasculation was carried out always before anthesis, with the help of a tweezers. Pollen grains were scattered on stigmas of emasculated flowers, which were tagged in sequence to avoid misidentification.

The ten hybrids and five parents and, in addition, two check cultivars, namely 'Caité' and 'Imbuia' were evaluated under field conditions in the experimental station of the Empresa de Pesquisa Agropecuária do Estado do Rio de Janeiro (PESAGRO-Rio), in Campos dos Goytacazes, Rio de Janeiro (2119'23' S; 4119'40"W; 13 $\mathrm{m}$ asl), from June to September 2012. According to the Köppen classification system (1948), the climate in Northern Rio de Janeiro is type AW, tropical hot and humid, with dry winters and rainy summers, and annual rainfall around 1,152 $\mathrm{mm}$. The experiment was conducted in a complete randomized blocks design, with four replications and treatments allocated in plots with two 3-m long lines. Spaces between rows and plants were $1.0 \times 0.5 \mathrm{~m}$, respectively. Six plants per plot were assessed. Fertilization followed the recommendations, according to the soil analysis. Drip irrigation was used and crop practices followed the usual for 
tomatoes (Filgueira, 2008).

The following traits were assessed: Days to fruiting (DF) (number of days from transplanting until $50 \%$ of the plants in the plot presenting ripe fruits in the first and/or second fork); Fruit length (FL), Fruit diameter (FDIAM), and Pericarp thickness (PT), in mm (average length and diameter, as well as pericarp thickness in a cross section, in 15 fruits per plot for all characteristics, using digital caliper); Fruit firmness (FF), \{in Newtons $(\mathrm{N})$, determined with a digital penetrometer probe with a $8-\mathrm{mm}$ diameter pointer, taking two readings per fruit (in the two opposite equatorial poles), in 15 fruits per plot\}; Total content of soluble solids (TSS) (in ${ }^{\circ}$ Brix, obtained with a digital refractometer, in 15 fruits per plot); Total number of fruits per plant (NFP) (count of all fruits in the experimental unit); Fruit average mass (FAM) (in g, ratio between the number and the total fruit weight within each plot); Yield (YLD) (product of the multiplication of NFP and FAM, in kg/ plant, estimate to ton $/ \mathrm{ha}$ ).

A diallel analysis was performed according to Method 2, Griffing's Model I (1956), which includes parents and $F_{1}$ hybrids, and assumes that only the experimental error has random effect (Griffing, 1956), using software GENES (Cruz, 2013) to run the analysis. Heterosis was estimated in relation to the average of parents and the standard cultivar, Caité.

\section{RESULTS AND DISCUSSION}

There were highly significant differences among genotypes at $1 \%$ probability (data not shown) for fruit length (FL), pericarp thickness (PT), fruit firmness (FF), total content of soluble solids (TSS), total number of fruits per plant (NFP), fruit average mass (FAM), and yield (YLD), which demonstrates the potential of parents for breeding. Mean squares were not significant for days to fruiting (DF) and fruit diameter (FDIAM).

Mean squares estimates related to the General Combining Ability (GCA) were significant at $1 \%$ probability for most of the traits, except for PT

Table 1. Estimates of effects of the General Combining Ability $\left(\hat{g}_{i}\right)$ for fruit length, pericarp thickness, fruit firmness, total content of soluble solids, total number of fruits per plant, fruit average mass, and yield in five tomato parents with fruits of dual use, evaluated on a complete diallel design without reciprocal (estimativas dos efeitos da Capacidade Geral de Combinação $\left(\hat{g}_{i}\right)$ para comprimento do fruto, espessura do pericarpo, firmeza do fruto, teor de sólidos solúveis totais, número total de frutos por planta, massa média de frutos e produtividade de cinco genitores de tomateiro com frutos para dupla finalidade, em esquema de dialelo completo, sem os recíprocos). Campos dos Goytacazes, UENF, 2012.

\begin{tabular}{|c|c|c|c|c|c|c|c|}
\hline \multirow[b]{2}{*}{$\operatorname{Effects}\left(\hat{g}_{i}\right)$} & \multicolumn{7}{|c|}{ Agronomic traits ${ }^{1}$} \\
\hline & $\begin{array}{c}\text { FL } \\
(\mathbf{m m})\end{array}$ & $\begin{array}{c}\text { PT } \\
(\mathbf{m m})\end{array}$ & $\begin{array}{l}\text { FF } \\
\text { (N) }\end{array}$ & $\begin{array}{c}\text { TSS } \\
\left({ }^{\circ} \text { Brix }\right)\end{array}$ & NFP & $\begin{array}{c}\text { FAM } \\
(\mathrm{g})\end{array}$ & $\begin{array}{l}\text { YLD } \\
\text { (t/ha) }\end{array}$ \\
\hline B13LD & -2.78 & 0.08 & 0.64 & 0.21 & -2.14 & 0.56 & -3.68 \\
\hline Castone & -1.78 & 0.04 & 0.00 & 0.14 & 0.25 & -4.76 & -1.81 \\
\hline Massag-72 & 9.11 & -0.11 & -1.56 & 0.02 & -2.01 & 0.36 & -3.50 \\
\hline Viradoro & -4.23 & -0.15 & 0.37 & -0.36 & 3.12 & -3.38 & 3.68 \\
\hline Rio Grande & -0.33 & 0.15 & 0.56 & -0.02 & 0.80 & 7.21 & 5.31 \\
\hline
\end{tabular}

${ }^{1} \mathrm{FL}=$ fruit lenght (comprimento do fruto); $\mathrm{PT}=$ pericarp thickness (espessura do pericarpo); $\mathrm{FF}=$ fruit firmness (firmeza dos frutos); $\mathrm{TSS}=$ total content of solube solids (teor total de sólidos solúveis); $\mathrm{NFP}=$ total number of fruits per plant (número total de frutos por planta); $\mathrm{FAM}=$ fruit average mass (massa média de frutos); YLD= yield (produtividade).

and $\mathrm{FF}$, in which mean squares were significant only at $5 \%$ of probability. Considering the Specific Combining Ability (SCA), estimates for FF, TSS, NFP, and YLD were significant at $1 \%$ probability, while for FAM, at 5\% probability. Therefore, we observed the expression of both non-additive and additive gene effects controlling FF, TSS, NFP, FAM, and YLD in the hybrids studied. Estimates of the SCA square components revealed that nonadditive effects were stronger for $\mathrm{FF}$, NFP, FAM, and YLD. Hence, parents are well appropriate to interpopulational breeding programs that aim at making a practical use of heterosis. These results are consistent with those of Martinez et al. (1989) and Souza et al. (2012), who also found a superiority of dominance over additivity effects for traits related to fruit production in tomato.

On contrary, in fruit length (FL), the superiority of additive over nonadditive gene effects denotes that the best breeding option would be the development of new lines. Regarding pericarp thickness (PT) and total content of soluble solids (TSS), additive and non-additive effects were equally important, since the square values of GCA and SCA effects were virtually the same. So, when one wants gains in PT or TSS, parents can be used for developing both new lines and hybrids. Regarding TSS, our results meet those of Hannan et al. (2007), who also observed both additive and non-additive gene effects for this characteristic. However, our results disagree with the work of Ahmad et al. (2009), in which additive gene effects overcame those of dominance for TSS.

The General Combining Ability (GCA) refers to the concentration of genes with additive effects (Sprague \& Tatum, 1942). Parents with high and positive GCA estimates contribute significantly to increases in the expression of a given trait, while those with high and negative estimates contribute significantly to its reduction. Thus, those parents with the highest GCA values should be the ones selected for breeding when the goal is to develop new lines and advance generations in autogamous plants (Ramalho et al., 1993).

Cultivars Viradoro and Rio Grande, used as parents, were the only two genotypes to provide positive $\hat{g}_{i}$ estimates for yield, with values of 3.68 and 5.31, respectively (Table $1)$. Therefore, both cultivars tend to contribute to increases in fruit yield in the crosses they take part in. Cultivars Viradoro and Rio Grande also had $\hat{g}_{i}$ positive estimates for number of fruits 
Table 2. Estimates of effects of the Specific Combining Ability $\left(\hat{s}_{i i}\right.$ and $\left.\hat{s}_{i j}\right)$ for fruit length, pericarp thickness, fruit firmness, total content of soluble solids, total number of fruits per plant, fruit average mass, and yield, evaluated in hybrids obtained out of crosses of five parents with fruits of dual use, evaluated on a complete diallel design without reciprocal \{estimativas dos efeitos da capacidade específica de combinação $\left(\hat{s}_{i i}\right.$ e $\left.\hat{s}_{i j}\right)$ para comprimento do fruto, espessura do pericarpo, firmeza do fruto, teor de sólidos solúveis totais, número total de frutos por planta, massa média de frutos e produtividade, avaliados em híbridos obtidos do cruzamento de cinco genitores de tomateiro com frutos de dupla finalidade, em esquema de dialelo completo, sem os recíprocos\}. Campos dos Goytacazes, UENF, 2012.

\begin{tabular}{|c|c|c|c|c|c|c|c|}
\hline \multirow{2}{*}{ Effects $\left(\hat{s}_{i i}\right.$ and $\left.\hat{s}_{i j}\right)$} & \multicolumn{7}{|c|}{ Agronomic traits $^{1}$} \\
\hline & FL (mm) & PT (mm) & FF (N) & TSS ( ${ }^{\circ}$ Brix) & NFP & FAM (g) & YLD (t/ha) \\
\hline $\mathrm{P}_{1} \mathrm{X} \mathrm{P}_{1}$ & 1.76 & -0.08 & 1.76 & 0.12 & -6.08 & 4.81 & -9.66 \\
\hline $\mathrm{P}_{2} \mathrm{X} \mathrm{P}_{2}$ & 1.27 & 0.24 & 2.41 & 0.05 & -0.12 & 9.75 & 4.83 \\
\hline $\mathrm{P}_{3} \mathrm{X} \mathrm{P}_{3}$ & 1.40 & 0.09 & 0.82 & 0.01 & -0.01 & 10.14 & 5.05 \\
\hline $\mathrm{P}_{4} \mathrm{X} \mathrm{P}_{4}$ & -0.45 & -0.21 & 1.68 & -0.12 & -7.36 & -0.74 & -13.28 \\
\hline $\mathrm{P}_{5} \mathrm{XP}_{5}$ & -0.66 & -0.24 & 0.80 & -0.02 & -3.40 & 1.48 & -5.72 \\
\hline $\mathrm{P}_{1} \mathrm{X} \mathrm{P}_{2}$ & -0.52 & -0.07 & 0.99 & 0.16 & -3.86 & -1.61 & -7.50 \\
\hline $\mathrm{P}_{1} \mathrm{X} \mathrm{P}_{3}$ & -1.71 & -0.06 & -1.93 & -0.21 & -2.60 & -4.91 & -7.05 \\
\hline $\mathrm{P}_{1} \mathrm{X} \mathrm{P}_{4}$ & -0.77 & -0.08 & -3.64 & -0.29 & 9.88 & 1.35 & 19.26 \\
\hline $\mathrm{P}_{1} \mathrm{X} \mathrm{P}_{5}$ & -0.51 & 0.37 & 1.07 & 0.10 & 8.75 & -4.45 & 14.61 \\
\hline $\mathrm{P}_{2} \mathrm{X} \mathrm{P}_{3}$ & -2.33 & -0.41 & -2.65 & -0.29 & -2.87 & -10.48 & -9.95 \\
\hline $\mathrm{P}_{2} \mathrm{XP}_{4}$ & 1.79 & 0.19 & -0.65 & 0.00 & 5.25 & -1.14 & 8.20 \\
\hline $\mathrm{P}_{2} \mathrm{XP}_{5}$ & -1.48 & -0.20 & -2.50 & 0.02 & 1.72 & -6.26 & -0.39 \\
\hline $\mathrm{P}_{3} \mathrm{XP}_{4}$ & -1.10 & 0.15 & 2.02 & 0.53 & 4.39 & -5.69 & 4.40 \\
\hline $\mathrm{P}_{3} \mathrm{XP}_{5}$ & 2.34 & 0.15 & 0.92 & -0.06 & 1.12 & 0.79 & 2.51 \\
\hline $\mathrm{P}_{4} \mathrm{XP}_{5}$ & 0.98 & 0.15 & -1.08 & -0.01 & -4.80 & 6.96 & -5.29 \\
\hline
\end{tabular}

${ }^{1} \mathrm{FL}=$ fruit lenght (comprimento do fruto); $\mathrm{PT}=$ pericarp thickness (espessura do pericarpo); $\mathrm{FF}=$ fruit firmness (firmeza dos frutos); $\mathrm{TSS}=$ total content of solube solids (teor total de sólidos solúveis); NFP= total number of fruits per plant (número de total de frutos por planta); $\mathrm{FAM}=$ fruit average mass (massa média de frutos); $\mathrm{YLD}=$ yield (produtividade).

per plant (NFP) and fruit firmness (FF). For the later, parent B13LD also had positive $\hat{g}_{i}$ estimates (Table 1). These genotypes contribute to increase the fruit ability to stand bulk transport, as well as mechanized harvesting, which

are important traits in a dual purpose tomato cultivar, as both the fresh market and the processing industry demand good fruit firmness, especially when production fields are far from consumers and industries (Embrapa, 2012). This

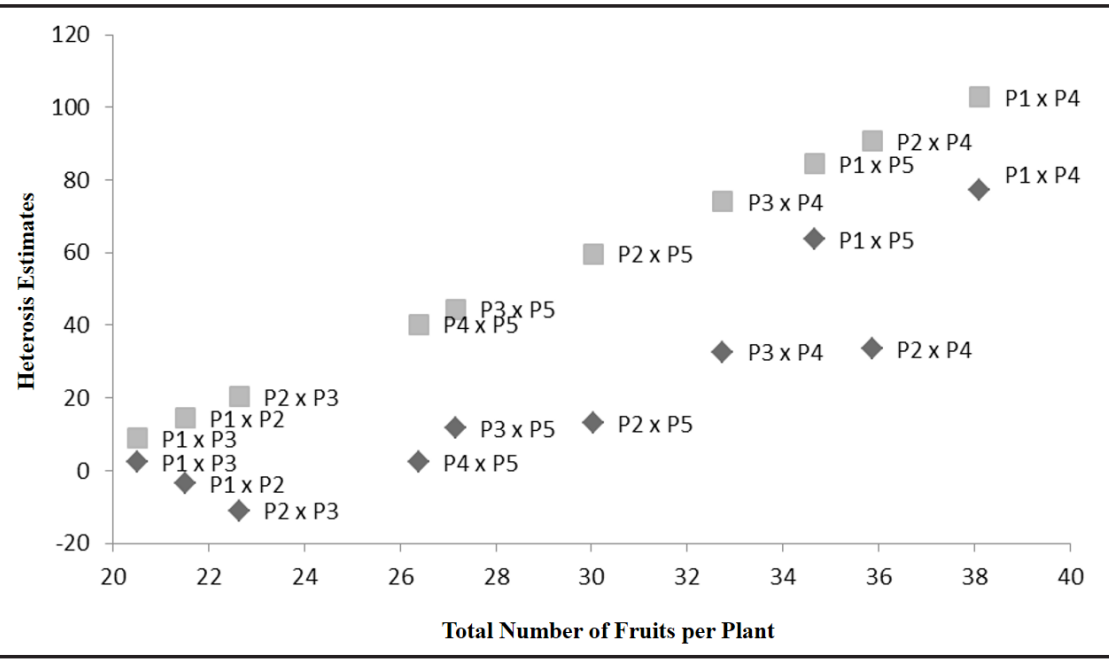

Figure 1. Heterosis estimates for total number of fruits per plant in relation to the parent mean (diamond) and to the standard cultivar (square) \{heterose para número total de frutos por planta em relação à média dos pais (losango) e à cultivar-padrão (quadrado)\}. Campos dos Goytacazes, UENF, 2012. is a particularly interesting remark for countries like Brazil and Mozambique, where the road network, especially in rural areas, are very often inadequate for the flowing of perishable products.

Although cultivars Viradoro and Rio Grande have expressed positive $\hat{g}_{i}$ estimates for fruit firmness (FF), total number of fruits per plant (NFP), and yield (YLD), none of them showed promising results for total content of soluble solids (TSS). As long as TTS is concerned, parents B13LD, Castone, and Massag-72 gave positive $\hat{g}_{i}$ estimates; while B13LD and Castone, along with cultivar Rio Grande, also had positive $\hat{g}_{i}$ values for pericarp thickness (PT), and therefore tend to contribute to increases in these traits in the crosses they are included. These are valuable parents for developing tomato cultivars for both table and processing fruits, since thicker pericarps contribute to both fruit quality and yield (Marim et al., 2009). However, it is important to evaluate the performance of these parents in other mating combinations. 


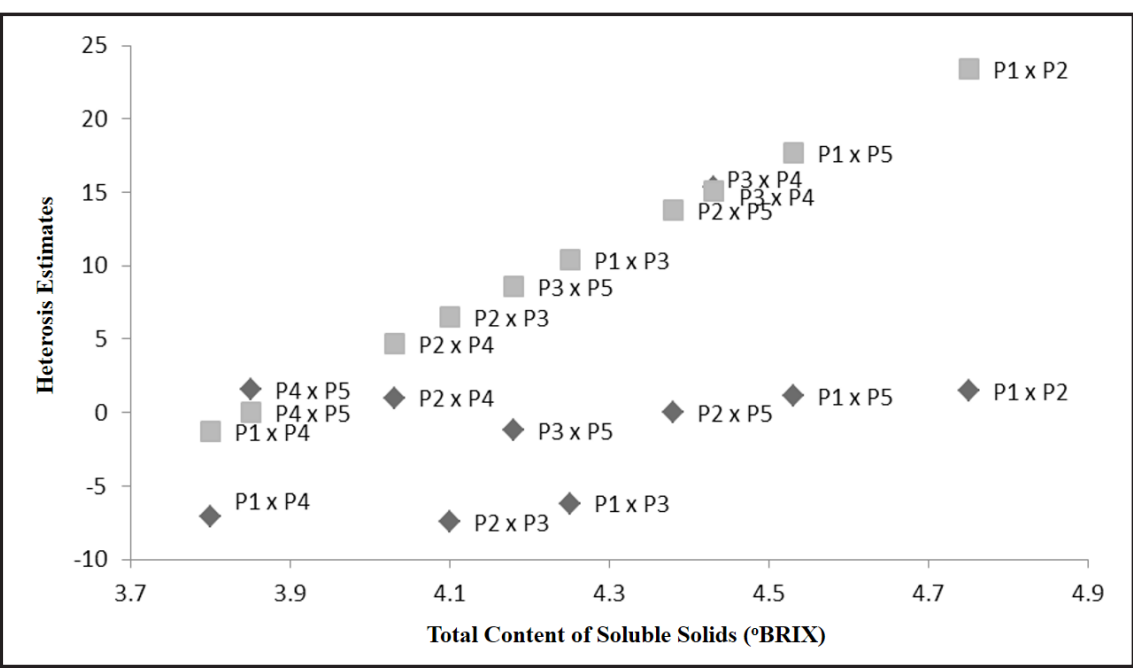

Figure 2. Heterosis estimates for total content of soluble solids in relation to the parent mean (diamond) and to the standard cultivar (square) \{heterose para teor total de sólidos solúveis em relação à média dos pais (losango) e à cultivar-padrão (quadrado)\}. Campos dos Goytacazes, UENF, 2012.

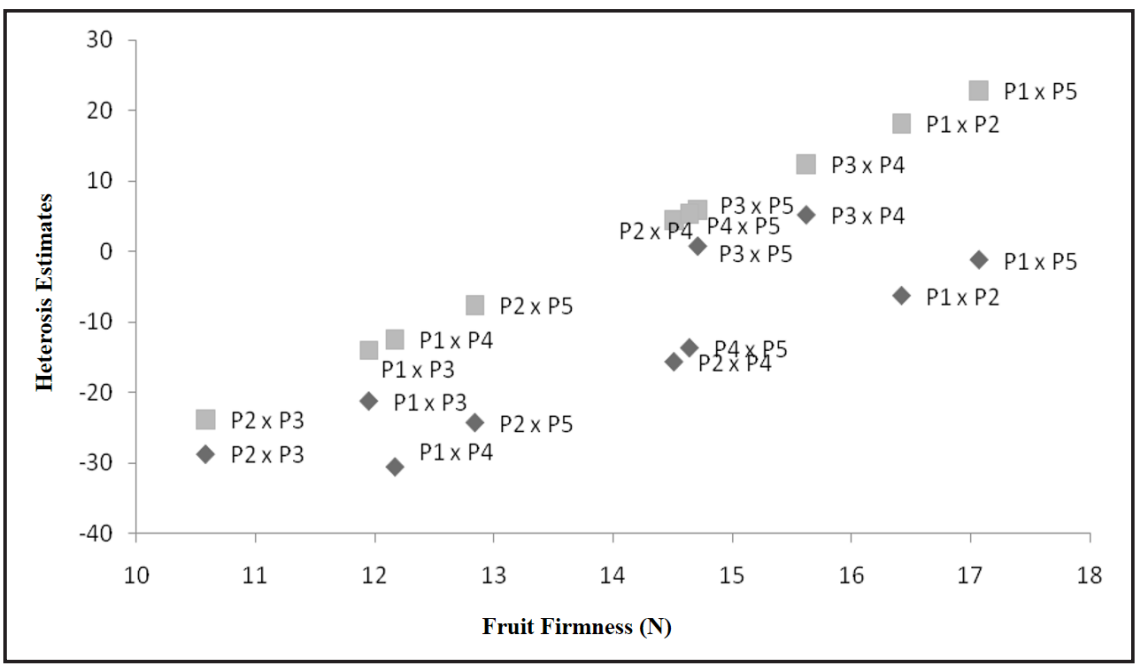

Figure 3. Heterosis estimates for fruit firmness in relation to the parent mean (diamond) and to the standard cultivar (square) \{heterose para firmeza de frutos em relação à média dos pais (losango) e à cultivar-padrão (quadrado)\}. Campos dos Goytacazes, UENF, 2012.

The SCA is the hybrid performance deviation over what would be expected based on the GCA of its parents. The ideal hybrid is the one that has the highest SCA estimate and, at the same time, comes from a cross in which the parent with the highest GCA was used (Cruz et al., 2012). Considering SCA estimates, combinations B13LD x 'Rio Grande' and Massag-72 x 'Viradoro' stood out, with potential to increase pericarp thickness (PT), fruit firmness (FF), total content of soluble solids (TSS), total number of fruits per plant had positive heterosis estimates (mean heterosis estimates in relation to parents and to the standard cultivar) for number of fruits per plant (NFP), especially in the crosses B13LD x 'Viradoro' (77.18 and 102.77\%), B13LD x 'Rio Grande' (63.73 and 84.41\%), Castone x 'Viradoro' (33.46 and 90.85\%), and Massag-72 x 'Viradoro' (32.70 and $74.20 \%$ ) (Figure 1). These hybrids had favorable and positive heterosis estimates for yield (YLD), but negative heterosis estimates for fruit average mass (FAM). The lack of heterotic effects for FAM can be associated with the type of inheritance, to the lack of dominance or occurrence of partial dominance for fruit size (Maluf et al., 1982). In these cases, when parents do not diverge much for a characteristic, hybrid performance tends to converge to that of its parents. These results match the studies of Maluf et al. (1982), Maciel et al. (2011) and Souza et al. (2012).

The total content of soluble solids on fruits (TSS) is a key trait, as it influences final product flavor and consistency, and ultimately determines the final yield after processing. As far as TSS is concerned, the best hybrid combinations were B13LD x Castone, B13LD x 'Rio Grande', Massag-72 x 'Viradoro', B13LD x Massag-72, Massag-72 x 'Rio Grande', which expressed the highest heterotic values in relation to the standard cultivar (Figure 2). Regarding fruit firmness (FF), there were negative HMP values for all hybrids, except Massag-72 x 'Viradoro', which expressed a positive heterotic value $(5 \%)$. Hybrids that stood out to TSS also had positive heterotic values when contrasted to the FF scores of the standard cultivar (Figure 3). Positive heterosis for FF becomes especially important when resistance during bulk transportation is an issue, independently of the tomato end use (Resende et al., 1999; Garg \& Cheema, 2011). In the present context, FF is indisputably relevant, since production zones are often remote in relation to trade centers both in Brazil and Mozambique.

This work gains in relevance when one considers that breeders and seed companies are rare in Mozambique; and even further, when its results, in 
addition to being useful as they currently stand, can be additionally exploited as a research line within the country. The cross B13LD x 'Rio Grande' definitely outstood: high potential for table and industry, positive values of heterosis and SCA for FF, TSS, NFP, and YLD. Other promising combinations were B13LD x Castone, Massag-72 x 'Viradoro', and Massag-72 x 'Rio Grande'. These crosses, in spite of not showing potential to provide increases in YLD, had positive heterosis for FF, TSS, and NFP, all traits of interest for tomato cultivars of dual purpose.

The development of new tomato genotypes, either hybrids or inbred lines, whose fruits simultaneously meet quality criteria for both fresh consumption and processing, is an asset for several producing regions. In Brazil, these genotypes can provide smallholders with the freedom of choice between selling fresh tomatoes and processing them in small familybased industries. In Mozambique, such genotypes are strategic to increase production and encourage local tomato farmers.

\section{ACKNOWLEDGEMENTS}

Authors would like to thank the Ministries of Agriculture and of Science and Technology of Mozambique, for supporting the first author; the Universidade Estadual do Norte Fluminense Darcy Ribeiro, for hosting António Jacinto P. Grace as a graduate student in the Graduation Program in Plant Science; the Conselho Nacional de Desenvolvimento Cientifico e Tecnológico $(\mathrm{CNPq})$, for granting the fellowship, and the Fundação Carlos Chagas Filho de Amparo à Pesquisa do
Estado do Rio de Janeiro (FAPERJ), for the financial support.

\section{REFERENCES}

AHMAD S; QUAMRUZZAMANAKM; ISLAM MR. 2011. Estimate of heterosis in tomato (Solanum lycopersicum). Bangladesh Journal of Agricultural Research 36: 521-527.

AHMAD S; QUAMRUZZAMAN AKM; UDDI NM. 2009. Combining ability estimates of tomato in late summer. SAARC Journal of Agriculture 7: 43-56.

CAMARGO AMMP; CAMARGO FILHO P; ALVES HS; CAMARGO FILHO WP. 2006. Desenvolvimento do sistema agroindustrial de tomate. Informações econômicas 36: 53-65.

CRUZ CD. 2013. GENES - a software package for analysis in experimental statistics and quantitative genetics. Acta Scientiarum 35: 271-276.

CRUZ CD; REGAZZI AJ; CARNEIRO PC. 2012. Modelos biométricos aplicados ao melhoramento genético. Viçosa: UFV. 514p.

Embrapa Hortaliças. 2012, 6 de setembro. Sistemas de produção. Cultivo de tomate industrial. Disponível em: http://www.Cnptia. embrapa.br

FAO. 2013, 22 de março. Disponível em: http:// www.faostat.fao.org.

FILGUEIRA FAR. 2008. Novo manual de olericultura: agrotecnologia moderna na produção e comercialização de hortaliças. Viçosa: UFV. 402p.

GARG N; CHEEMA DS. 2011. Assessment of fruit quality attributes of tomato hybrids involving ripening mutants under high temperature conditions. Scientia Horticulturae 131: $29-38$

GRIFFING B. 1956. Concept of general and specific ability in relation to diallel crossing systems. Australian Journal of Biological Sciences 9: 462-93.

HANNAN MM; AHMED MB; ROY UK; RAZVY MA; HAYDAR A; RAHMAN, MA; ISLAM MA; ISLAM R. 2007. Heterosis, combining ability and genetics for brix, days to first fruit ripening and Yield in Tomato. Middle-East Journal of Scientific Research 2: $128-131$

IBGE. 2012, 28 de fevereiro. Disponível em: http://www.sidra.ibge.gov.br/home/estatística/ indicadores/agropecuária/lspa/lspa/.
KÖPPEN W. 1948. In Climatologia: Com um estúdio de los climas de la tierra. México: Fondo de cultura econômica, 478p.

MACIEL GM; MALUF WR; SILVA VF. 2011. Heterose e capacidade combinatória de linhagens de tomateiro em acilaçúcares. Ciência e Agrotecnologia 34: 1161-1167.

MALUF WR; MIRANDAJEC; CAMPO JP. 1982. Análise genética de um cruzamento dialélico de cultivares de tomateiro. Características referentes à produção de frutos. Pesquisa Agropecuária Brasileira 17: 633-641.

MARIM BG; SILVA DJ; CARNEIRO PCS; MIRANDA CV; MATTEDI AP; CALIMAN FRB. 2009. Variabilidade genética e importância relativa de caracteres em acessos de germoplasma de tomateiro. Pesquisa Agropecuária Brasileira 44: 1283-1289.

MARINHO CD; MARTINS FJO; AMARAL SCS; AMARAL JÚNIOR AT; GONÇALVES LSA; MELO MP. 2011. Revisiting the Brazilian scenario of registry and protection of cultivars: an analysis of the period from 1998 to 2010, its dynamics and legal observations. Genetics and Molecular Research 10: 792-809.

MARTINEZ PBA; SANINT PR; VALLEJO CFA. 1989. Análisis de la heterosis y de la habilidade combinatória entre diferentes cultivares de tomate, Lycopersicon esculentum a partir de um cruzamento dialelico. Acta Agrónomica 39: 24-33.

MELO PCT. 2011. Diagnóstico sobre a viabilidade da produção de sementes de hortaliças no sul de Moçambique. Maputo: Relatório final. 39p.

MINAG. 2011. Plano Econômico e Social. Maputo: Balanço Anual 2011. 110 p.

RAMALHO MAP; ARAÚJO LCA. 2011. Breeding self-pollinated plants. Crop Breeding and Applied Biotechnology SI: 1-7.

RAMALHOMAP;SANTOS JB;ZIMMERMANN MJO. 1993. Génetica quantitativa em plantas autógamas: aplicações ao melhoramento do feijoeiro. Goiânia: UFG. 271p.

RESENDE LV; MALUF WR; GOMES LAA; MOTA FMP; RESENDE JTV. 1999. Análise dialélica de firmeza de frutos em cultivares e linhagens de tomateiro (Lycopersicon esculentum). Ciência e Agrotecnologia 23: 12-18.

SOUZA LM; PATERNIANI MEA; MELO PCT; MELO AMT. 2012. Diallel cross among fresh market tomato inbreeding lines. Horticultura Brasileira 30: 246:251.

SPRAGUE GF; TATUM LA. 1942. General vs specific combining ability in single crosses of corn. Journal of American Society of Agronomy 34: 923-932. 